\title{
Lymphocytic hypophysitis: an underestimated disease affecting the sellar region
}

\section{Limfocytarne zapalenie przysadki: zbyt rzadko rozpoznawana choroba okolicy siodła tureckiego}

\author{
Bekir Tuğcu', Omur Gunaldi', Luffi Postalci', Osman Tanriverdi', Ender Ofluoglu', Nurten Sever \\ 12nd Neurosurgery Clinic, Bakrrköy Research and Training Hospital for Neurology, Neurosurgery and Psychiatry \\ 2Department of Pathology, Bakrrköy Sadi Konuk Research and Training Hospital
}

Neurologia i Neurochirurgia Polska 2011; 45, 2: 174-179

\begin{abstract}
Hypophysitis is an inflammation of the pituitary gland and includes a heterogeneous group of diseases presenting with impaired pituitary gland function. Hundreds of cases have been reported after Goudie and Pinkerton's initial report on a young postpartum woman who died after progressive lymphocytic infiltration of the adenohypophysis in 1962.

A 17-year-old woman presented with a three-year history of headache, galactorrhoea and excessive weight gain. The patient had used oral contraceptives for several years until one year previously. Her examination demonstrated only bilateral heteronymous hemianopsia. Laboratory investigation revealed elevated prolactin and decreased gonadotropin levels. Magnetic resonance imaging showed a sellar mass with suprasellar extension. Surgical removal of the lesion was performed via a transsphenoidal approach. A diagnosis of lymphocytic hypophysitis was confirmed by histopathological evaluation.

Hypophysitis is an underestimated disease affecting the pituitary gland. Cases are usually diagnosed as adenomas and treated with surgical removal. This case is presented due to the extremely rare infiltration of the pituitary gland by predominantly lymphocytes.
\end{abstract}

Key words: lymphocytic hypophysitis, pituitary adenoma, neuropathology.

\section{Streszczenie}

Zapalenia przysadki to niejednorodna grupa chorób manifestujących się zaburzoną czynnością przysadki. Od opublikowanego przez Goudiego i Pinkertona w 1962 r. opisu młodej kobiety, która zmarła po porodzie i u której stwierdzono limfocytarny naciek przedniego płata przysadki, opublikowano setki takich przypadków.

Siedemnastoletnia kobieta zgłosiła się z powodu utrzymujących się od trzech lat bólów głowy, mlekotoku i zwiększenia masy ciała. Przez kilka lat, aż do roku poprzedzającego zgłoszenie do lekarza, stosowała hormonalne środki antykoncepcyjne. W badaniu przedmiotowym stwierdzono jedynie obustronne różnoimienne niedowidzenie połowicze. W badaniach laboratoryjnych wykryto zwiększone stężenie prolaktyny i zmniejszone stężenia gonadotropin. W badaniu za pomocą rezonansu magnetycznego uwidoczniono guz siodła tureckiego wychodzący poza obręb siodła. Zmianę usunięto chirurgicznie $\mathrm{z}$ dostępu przezklinowego. W badaniu histopatologicznym potwierdzono rozpoznanie limfocytarnego zapalenia przysadki.

Zapalenie przysadki jest chorobą rozpoznawaną zbyt rzadko. U chorych rozpoznaje się zwykle gruczolaki i leczy się je chirurgicznie. Przypadek przedstawiono ze względu na wyjątkowo rzadko spotykany naciek przysadki, w którym dominowały limfocyty.

Słowa kluczowe: limfocytarne zapalenie przysadki, gruczolak przysadki, neuropatologia.

Correspondence address: Dr. Bekir Tuğcu, Sirpsindigi sok. Koksal apt 31/7, Merter-Istanbul, Turkey, e-mail: bekirtugcu@superonline.com Received: 24.03.2010; accepted: 23.12.2010 


\section{Introduction}

An inflammatory lesion of the pituitary gland is an extremely rare condition. The incidence of the disease is $1 / 10000000$ in the population. Primary hypophysitis is a form of strictly isolated inflammation of the pituitary gland. The lymphocytic form of primary hypophysitis is related to autoimmune dysfunction. Despite being rare, it is an increasingly recognized condition and has thus become an important entity in the differential diagnosis of non-secreting, space-occupying lesions of the sella turcica. We present a histologically proven case of primary hypophysitis.

\section{Case report}

A 17-year-old woman presented with three-year history of headache, galactorrhoea and excessive weight gain. The patient had used oral contraceptives for several years until one year previously.

The neurological examination was normal, fundus examination was within normal limits and no abnormalities were found in the visual field testing. The patient was referred to an ophthalmologist who diagnosed bilateral heteronymous hemianopsia. Preliminary laboratory investigations showed moderate hyperglycaemia $(218 \mathrm{mg} / \mathrm{dL})$, mild hyponatraemia $(133 \mathrm{mmol} / \mathrm{L})$ and leucocytosis $(12600 / \mu \mathrm{L})$. All the other routine investigations were found to be normal. Assessment of the hormonal profile revealed elevated levels of prolactin

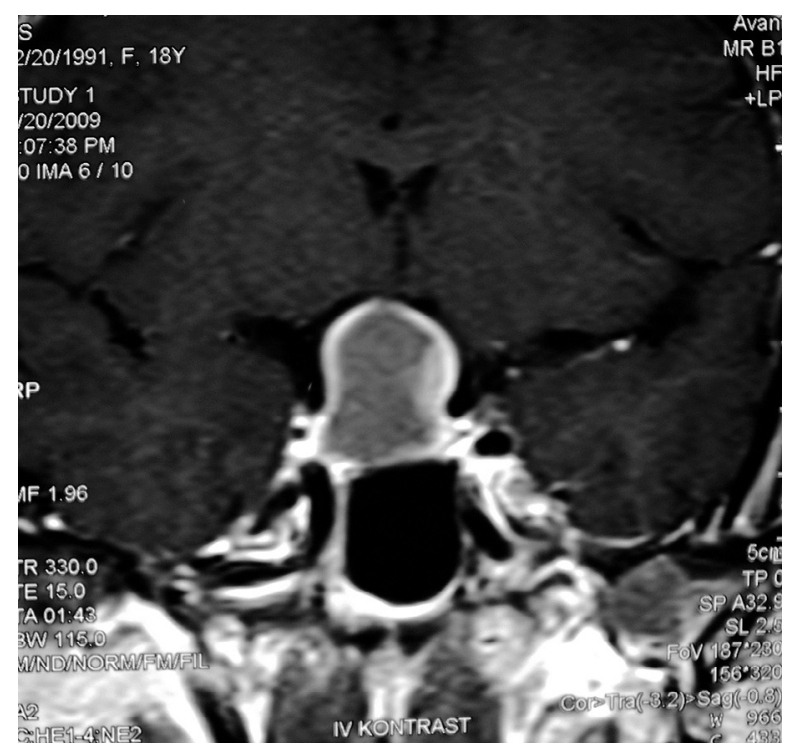

Fig. 1A. Coronal Tl-weighted MRI scan showing a sellar mass with homogeneous contrast enhancement
(452 $\mu \mathrm{g} / \mathrm{L}$, normal range: 3.3 to $26.7 \mu \mathrm{g} / \mathrm{L}$ ) and decreased levels of gonadotropins such as FSH $(0.67 \mathrm{mIU} / \mathrm{L}$, normal range: 3.8 to $4.5 \mathrm{mIU} / \mathrm{L})$ and $\mathrm{LH}(0.29 \mathrm{mIU} / \mathrm{L}$, normal range: 2.1 to $10.9 \mu \mathrm{IU} / \mathrm{L})$. Other hormonal investigations were within normal limits.

Magnetic resonance imaging (MRI) of the pituitary showed a complex, partially cystic sellar mass with suprasellar extension. The lesion showed a ring-shaped contrast enhancement with a large non-enhancing central component following gadolinium injection (Fig. 1A-B).

The patient subsequently underwent a transsphenoidal excision of the pituitary lesion. During the operation, the lesion was observed to be soft with yellow discolouration. Histopathological evaluations revealed disruption of the normal histological architecture and destruction of the parenchyma. There was predominantly lymphocytic cell infiltration in the anterior pituitary lobe. Plasma cells were also common. Histopathological features were consistent with lymphocytic hypophysitis (Fig. 2A-B).

The postoperative period was uneventful and the patient was discharged on the fifth postoperative day with normal neurological findings. At three-month follow-up, a hormonal assessment revealed low gonadotropin levels such as FSH (1.07 mIU/L normal range: 3.8 to $4.5 \mathrm{mIU} / \mathrm{L})$ and $\mathrm{LH}(0.11 \mathrm{mIU} / \mathrm{L}$, normal range: 2.1 to $10.9 \mu \mathrm{IU} / \mathrm{L})$ and mildly elevated levels of prolactin $(66.15 \mu \mathrm{g} / \mathrm{L}$, normal range: 3.3 to $26.7 \mu \mathrm{g} / \mathrm{L})$. The hormonal imbalance detected during the preoperative period was continuing in the late postoperative

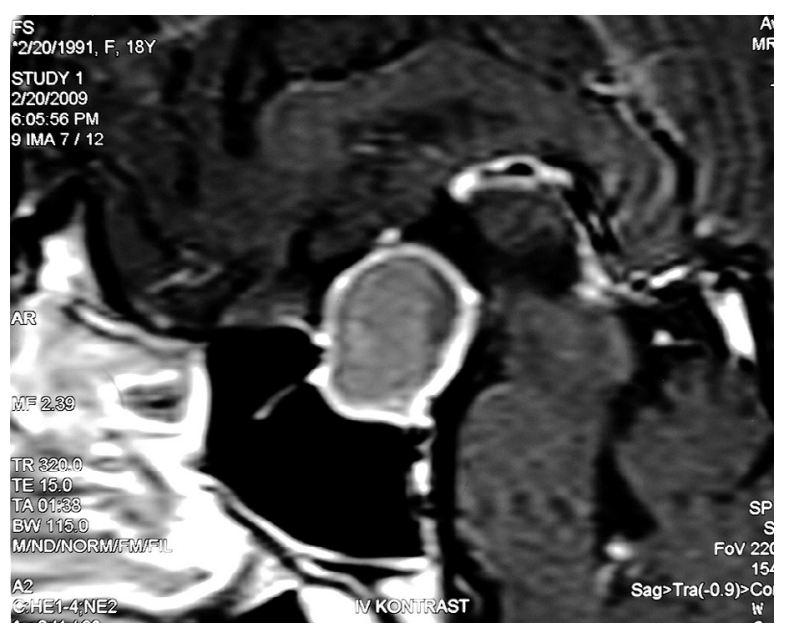

Fig. IB. Sagittal TI-weighted MRI scan showing a sellar mass extending into the suprasellar region with homogeneous contrast enhancement 


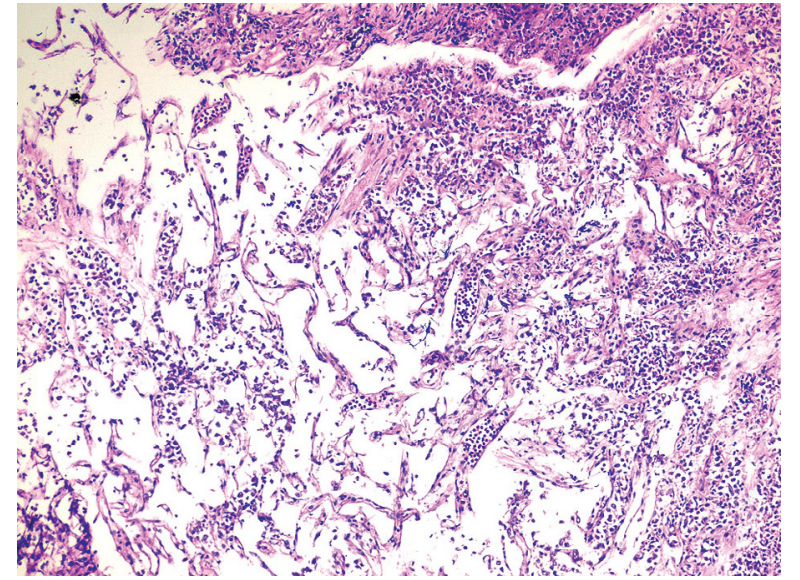

Fig. 2A. Photomicrographs showing disruption of the normal histological architecture and destruction of the parenchyma (HE stain, original magnification $\times 100)$

follow-up. The leucocyte count returned to normal in the postoperative period. MRI at six-month follow-up revealed complete removal of the lesion (Fig. 3).

\section{Discussion}

Hypophysitis is an inflammation of the pituitary gland and represents approximately $5 \%$ of all symptomatic disorders involving the pituitary gland. The term 'hypophysitis' refers to a heterogeneous group of disorders that can be primary or secondary.

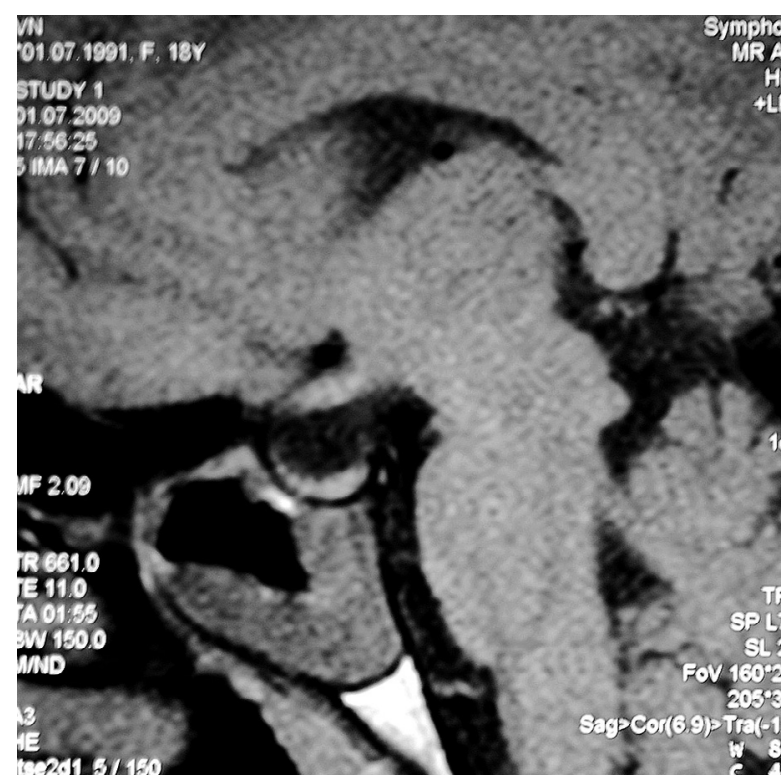

Fig. 3. Postoperative sagittal TI-weighted MRI showing complete removal of the lesion

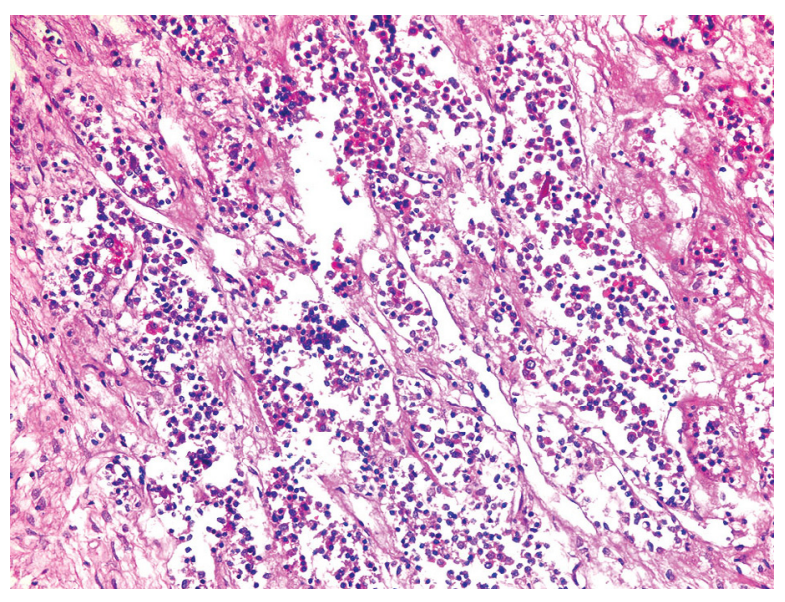

Fig. 2B. Histopathology demonstrating that lymphocytes are the predominant cell type infiltrating the anterior pituitary lobe (HE stain, original magnification $\times$ 400)

Secondary hypophysitis is a rare condition and the causes include infectious diseases such as tuberculosis and brucellosis, vasculitides such as Wegener's granulomatosis, and other diseases such as neurosarcoidosis and Langerhans cell histiocytosis.

Primary hypophysitis is a strictly isolated inflammation of the pituitary gland without any systemic inflammation. Primary hypophysitis comprises three distinct histopathological subtypes: lymphocytic, granulomatous and xanthomatous. The lymphocytic form seems to be strongly correlated with autoimmune dysfunction and is usually used as synonymous with autoimmune hypophysitis.

In 1962, Goudie and Pinkerton reported a young postpartum woman who died after progressive adrenal insufficiency [1]. Postpartum examinations showed a marked lymphocytic infiltration of the adenohypophysis. Following this report, hundreds of cases have been reported in the literature [2].

Pituitary autoimmunity makes a complex spectrum. Caturegli described four distinct conditions as part of the spectrum of pituitary autoimmunity [2]: (1) autoimmune hypophysitis - histologically proven or clinically suspected; (2) antipituitary antibodies in isolated pituitary hormone deficiency; (3) pituitary antibodies in other diseases; and (4) pituitary antibodies in non-autoimmune pituitary diseases.

Autoimmune hypophysitis is a rare inflammatory disorder of the pituitary, but it is increasingly being suspected in clinical practice. Lymphocytic hypophysitis poses a significant diagnostic problem since it mimics other pituitary masses in terms of the clinical and radiological features [3-7]. 


\section{Clinical features}

Lymphocytic hypophysitis usually manifests like other sellar mass lesions. Headache and visual disturbances are the most common symptoms [8]. Symptoms due to the hormonal abnormalities such as galactorrhoea, amenorrhoea, weight loss, hypotension, fatigue and emotional liability are common. Patients with lymphocytic hypophysitis typically present with the symptoms and signs of multiple pituitary hormone deficiency, whereas isolated hormone deficiency is seen rarely $[2,9]$. A review of the literature showed that adrenocorticotropin hormone $(\mathrm{ACTH})$ deficiency is the most common abnormality and affects more than a half of all patients (57\%) [2]. Other hormone deficiencies are characterized by decreased levels of gonadotropins (52\%), thyroid stimulating hormone (TSH) (49\%) and growth hormone $(\mathrm{GH})(39 \%)$. Hyperprolactinaemia occurs in $23 \%$ of all patients only. Gutenberg et al. reported a series of 31 histologically proven cases of primary hypophysitis [9] and demonstrated that gonadal axis deficits are the most common hormonal disturbances, followed by those of the adrenal and thyroid axis. In one-third of all patients, the posterior pituitary lobe hormones are found to be affected, and their deficiency usually causes polyuria and polydipsia. Posterior lobe involvement in patients with lymphocytic hypophysitis may be isolated, which is identified as infundibuloneurohypophysitis, or it may be associated with adenohypophysitis and referred to as pan-hypophysitis. Diabetes insipidus is usually accompanied by hyperprolactinaemia and can be attributed to pituitary stalk infiltration and thickening. The preferential deficiency of the pituitary gland hormones may prove useful to differentiate lymphocytic hypophysitis from the pituitary adenomas, which are the most frequent mass lesions of the sella turcica region. In patients with lymphocytic hypophysitis, ACTH secreting cells are found to be more vulnerable to inflammation than the other cells of the pituitary gland. Therefore, these patients show symptoms of ACTH deficiency during the early phases of the disease whereas in adenoma patients ACTH secretion is affected in later stages.

\section{Radiological findings}

The radiological distinction between lymphocytic hypophysitis and other sellar and/or suprasellar mass lesions can pose some difficulty. The true diagnosis can only be made histologically. On MRI imaging, lym- phocytic hypophysitis typically appears as an enlarged pituitary mass that displays hypointense or isointense signals on T1-weighted images as well as hyperintense signals on T2-weighted images. Some patients show a heterogeneous or ring-shaped enhancement with a cystic area on MRI. In this regard, the nature of the lesion may cause confusion when establishing a differential diagnosis between lymphocytic hypophysitis and cystic sellar lesions such as Rathke's cleft cysts, arachnoid cysts, dermoid cysts and epidermoid cysts. Hypophysitis usually shows marked intralesional and adjacent dural contrast enhancement. It is well documented that almost all macroadenomas and the majority of other intrasellar tumours (metastases, meningiomas and craniopharyngiomas) cause sellar enlargement. In contrast, a normal sized or slightly enlarged sellar fossa is typical in patients with lymphocytic hypophysitis.

Honegger et al. reported that the most characteristic feature of lymphocytic hypophysitis is a tongue-like extension of the lesion along the basal hypothalamus [10]. They also emphasized the importance of a normal-sized or slightly enlarged fossa in patients with lymphocytic hypophysitis. Another valuable finding is the enlargement of the pituitary stalk. Although there has been great interest in identifying distinguishable MRI features recently, current imaging modalities do not allow a definitive diagnosis of lymphocytic hypophysitis.

\section{Management}

Treatment options include conservative management, steroid therapy and surgical therapy. Optimal treatment is still controversial due to the variable natural history of the disease [2]. A minority of the patients may improve spontaneously without any medical or surgical treatment $[11,12]$. Furthermore, there has been a report of a patient who recovered spontaneously after becoming pregnant. More than a half of patients underwent surgical resection. Thus, it can be speculated that lymphocytic hypophysitis sometimes behaves like other autoimmune disorders which are characterized by remissions and relapses.

Presenting symptoms and the existence of pregnancy may constitute a critical role to establish a management protocol. If the patient presents with signs due to a mass effect, surgical intervention should be preferred $[10,13]$. Especially in patients with progressive neurological deficits or those presenting with life-threatening symptoms, urgent debulking is indicated. On the other hand, if the presentation is less dramatic and a mass 
effect is absent, conservative management may be considered with or without obtaining a biopsy sample. Corticosteroids can be administered without a biopsy sample and may even induce a reduction in the volume of the lesion. Beressi et al. reported on a patient with lymphocytic hypophysitis, who was treated with corticosteroids [13]. Gutenberg et al. in their large series of primary hypophysitis reported that lymphocytic hypophysitis related to pregnancy and isolated lymphocytic hypophysitis were associated with additional autoimmune diseases [9]. However, the improvement after steroid therapy is usually incomplete and also transient [14]. This condition occurs especially in xanthomatous and granulomatous subtypes. There was only one prospective study that demonstrated a therapeutic effect of glucocorticoid administration on patients with lymphocytic hypophysitis [15]. In the literature, most of the primary hypophysitis cases were diagnosed histopathologically after transsphenoidal resection or sampling. For this reason, knowledge about the effect of transsphenoidal surgery on primary hypophysitis is sufficient. Outcome after decompression is generally favourable and should be preferred for patients with optic pathway compression.

Glucocorticoid therapy is recommended only in patients with strongly suspected lymphocytic hypophysitis and absence of serious mass effect. Xanthomatous hypophysitis is suspected in patients with a limited deficiency of adrenal axis hormones who have a poor response to glucocorticoid therapy.

\section{Pathological findings}

Lymphocytic hypophysitis is characterized pathologically by destruction of the anterior and/or posterior pituitary lobe by an inflammatory infiltrate primarily rich in lymphocytes. Plasma cells are also common. Eosinophils, macrophages and neutrophils are other infiltrating cells. Infiltrating cells disrupt normal pituitary parenchyma and in later stages it becomes replaced by fibrous tissue. Multinucleated giant cells are more typical for granulomatous hypophysitis and rarely occur in lymphocytic hypophysitis.

\section{Postoperative course}

Most of the studies show recovery of pituitary functions, especially in the gonadal axis and hyperprolactinaemia, after transsphenoidal surgery in more than half of patients with lymphocytic hypophysitis. Most patients, however, require some form of hormone replacement therapy such as administration of corticosteroids [2,9, 16]. Headache and visual field defects usually improve shortly after surgical treatment $[2,9,16]$. The post-surgical course of our patient was similar to the majority of those reported in the literature. Her visual field defect resolved by the first follow-up but we did not observe any improvement of hormonal imbalance in the present case.

In summary, lymphocytic hypophysitis is an autoimmune inflammation of the pituitary gland and is likely to be more common than has previously been thought. The definite diagnosis can only be obtained histologically. Most cases are misdiagnosed as pituitary adenoma in presurgical evaluation. We believe that detailed pre-surgical evaluation of hormone levels, especially the preferential deficiency of the pituitary gland hormones, may improve the accuracy of the diagnosis. Outcome after transsphenoidal surgery is generally favourable. Although corticosteroid treatment is an alternative to surgery and improvement may be achieved after medical management, surgical intervention should be preferred in patients with findings suggesting the presence of a serious mass effect, risk of vision loss and life-threatening symptoms.

\section{Disclosure}

Authors report no conflict of interest.

\section{References}

1. Goudie R.B., Pinkerton PH. Anterior hypophysitis and Hashimoto's disease in a young woman. J Pathol Bacteriol 1962; 83: 584-585.

2. Caturegli P., Lupi I., Landek-Salgado M., et al. Pituitary autoimmunity: 30 years later. Autoimmun Rev 2008; 7: 631-637.

3. Flanagan D.E., Ibrahim A.E., Ellison D.W., et al. Inflammatory hypophysitis - the spectrum of disease. Acta Neurochir 2002; 144: 47-56.

4. Freda P.U., Wardlaw S.L., Post K.D. Unusual causes of sellar/parasellar massesin a large transphenoidal surgical series. J Clin Endocrinol Metab 1996; 81: 3455-3459.

5. Huang Y.Y., Lin S.F., Dunn P., et al. Primary pituitary lymphoma presenting as hypophysitis. Endocr $J$ 2005; 52: 543-549.

6. Nishikawa T., Takahashi J.A., Shimatsu A., et al. Hypophysitis caused by Rathke's cleft cyst. Case report. Neurol Med Chir (Tokyo) 2007; 47: 136-139.

7. Wong S., Lam W.Y., Wong W.K., et al. Hypophysitis presented as inflammatory pseudotumor in immunoglobulin G4-related systemic disease. Hum Pathol 2007; 38: 1720-1723. 
8. Parent A.D. Lymphoid hypophysitis. In: Wilkins R.H., Rengachary S.S. [eds.]. Neurosurgery. $2^{\text {nd }}$ ed. McGrarw-Hill, New York 1996; 1347-1355.

9. Gutenberg A., Hans V., Puchner M.J., et al. Primary hypophysitis: clinical-pathological correlations. Eur J Endocrinol 2006; 155: 101-107.

10. Honegger J., Fahlbusch R., Bornemann A., et al. Lymphocytic and granulomatous hypophysitis: experience with nine cases. Neurosurgery 1997; 40: 713-722.

11. Castle D., de Villiers J.C., Melvill R. Lymphocytic adenohypophysitis: report of a case with demonstration of spontaneous tumour regression and a review of the literature. Br J Neurosurg 1988; 2: 401-405.

12. Ishihara T., Hino M., Kurahachi H., et al. Long term clinical course of two cases of lymphocytic hypophysitis. Endocr J 1997; 43: 433-440

13. Beressi N., Cohen R., Beressi J.P., et al. Pseudotumoral lymphocytic hypophysitis successfully treated by corticosteroid alone: first case report. Neurosurgery 1994; 35: 505-508.

14. Leung G.K., Lopes M.B., Thorner M.O., et al. Primary hypophsitis: a single-center experience in 16 cases. $J$ Neurosurg 2004; 101: 262-271.

15. Kristof R.A., Van Roost D., Klingmüller D., et al. Lymphocytic hypophysitis: non invasive diagnosis and treatment by high dose methylprednisolone pulse therapy? J Neurol Neurosurg Psychiatry 1997; 67: 398-402.

16. Ng W.H., Gonzales M., Kaye A.H. Lymphocytic hypophysitis. J Clin Neurosci 2003; 10: 409-413. 